\title{
Surface Roughness and Wettability Variation: The effect of Cutting Distance during Milling of Pinus Radiata Wood
}

\section{Promjene hrapavosti i svojstva kvašenja površine: utjecaj duljine rezanja tijekom blanjanja borovine}

\author{
Original scientific paper • Izvorni znanstveni rad \\ Received-prispjelo: 4. 9. 2015. \\ Accepted-prihvaćeno: 5. 5. 2016. \\ UDK: $630 * 812.732 ; 630 * 812.22 ; 630 * 847 . ; 674.031 .475 .49$ \\ doi:10.5552/drind.2016.1531
}

\begin{abstract}
The variation of the machined surface properties is usually described in terms of changes in cutting parameters. However, the effect of the cutting distance should be considered, as it further shows the influence of the cutting tool wear. In order to assess the effect of the cutting distance on roughness and wettability of Pinus radiata wood surfaces, three conditions of feed speed and cutting speed were applied on cutting distance of 0 to 10000 meters. This study describes the effect of machining parameters on the behavior of roughness and wettability through the cutting distance, and the interaction of both surface properties is also discussed. The variation of surface roughness in function of the cutting distance is not directly related to variations in the surface wettability. It was, therefore, concluded that is was not reliable to consider only the surface roughness to explain the wetting behavior of a heterogeneous surface such as wood.
\end{abstract}

Key words: cutting distance, roughness, wettability, contact angle, wood, milling

SAŽETAK • Varijacije svojstava obrađene površine drva obično se opisuju kao posljedica promjene parametara obrade. Međutim, treba uzeti u obzir i učinak duljine rezanja jer to dodatno pokazuje utjecaj istrošenosti reznog alata. Kako bi se procijenio učinak duljine rezanja na hrapavost i svojstvo kvašenja površine drva bora (Pinus radiate), pri blanjanju na duljini od 0 do 10000 metara primijenjene su tri različite posmične brzine i brzine rezanja. U radu se opisuje utjecaj parametara obrade na hrapavost i svojstvo kvašenja obrađene površine u ovisnosti o duljini rezanja, a objašnjena je i interakcija tih dvaju svojstava obrađene površine. Varijacije hrapavosti površine u ovisnosti o duljini rezanja nisu izravno povezane s varijacijama svojstva kvašenja površine. Zaključeno je da za određivanje svojstva kvašenja heterogene površine materijala kao što je drvo nije pouzdano uzimati u obzir samo hrapavost njegove površine.

Ključne riječi: duljina rezanja, hrapavost, svojstvo kvašenja, kontaktni kut, drvo, blanjanje

\footnotetext{
${ }^{1}$ Authors are assistant proffesors and associate professor at the Forest Product Laboratory, Institute of Forests and Society, Faculty of Forest Science and Natural Resources, Austral University of Chile, Campus Isla Teja, Casilla 567, Valdivia, Chile.

Autori su docenti i izvanredni profesor Laboratorija za šumske proizvode, Fakultet znanosti o šumama i prirodnim resursima, Južno sveučilište u Čileu, Valdivia, Čile.
} 


\section{INTRODUCTION}

\section{UVOD}

The characterization of wood cutting surfaces is very important as it normally interacts with adhesives, paints and varnishes. Roughness and wettability are surface properties that are normally used to assess surface quality. The characterization of surface quality depends on many influencing factors and can be related both to wood properties and machining conditions (Magoss, 2008). Dundar et al., (2008) and Magoos (2008) found that an increase in cutting speed decreased the surface roughness. On the other hand, by the increasing of the feed speed, the surface roughness is increased (Keturakis and Juodeikienè, 2007; Hernandez and Cool, 2008). Walinder (2000) explained that the intrinsic wood surface structure combined with the irregular surface structure resulting from different machining processes might cause variation in wood wettability. Hernandez and Cool (2008) found that an increment in feed speed affected the wetting of a surface. The authors considered that better wetting was associated with higher surface roughness. In a comparison of different types of wood surface machining, planed, sanded and disc sawn surfaces, Santoni and Pizzo (2011) found that the high roughness, produced in the sanding process made more wettable the sanding surfaces. Cool and Hernandez (2011) also measured better wettability on rough surfaces compared to smoother ones.

Nevertheless, the effect of those cutting parameters on surface properties is not constant due to the wear on the cutting tool by the effect of the cutting distance. This cutting distance was considered for limited cutting distances or the wear was reproduced artificially. The wood milling tools undergo wear during the cutting process, the mass of the tools decreases and the geometrical parameters change (Keturakis and Lisauskas, 2010). Surface quality is particularly sensitive to the changes in wear profile geometry (Sheikh and McKenzie, 1997). Itaya and Tsuchiya (2003) cited by Aknouche et al. (2009) concluded that the direct consequence of the cutting edge wear is the gradual loss of its ability to cut the machined material. These conditions also result in a poor wood surface quality. Keturakis and Juodeikiene (2007) modelled artificially the cutting edges of the knives and found that a decrease on tool edge blunt radius and feed rate during milling decreases the surface roughness of birch wood. Gilewicz et al. (2010), evaluated the wear by the effect of the cutting distance until 6000 meter on the surface properties and found almost a linear increase of $R_{\mathrm{z}}$ together with the tool wear. This study is intended to provide information on the variation of surface properties depending on the cutting distance in order to support decisions as to when to renew the cutting tool.

Therefore, the main objective of this study was to describe the behavior of roughness and wettability on Pinus radiate wood surfaces in function of the cutting distance during its machining.

\section{MATERIAL AND METHODS 2. MATERIJAL I METODE}

In this study, Pinus radiata $\mathrm{D}$. Don samples, see table 1, with a mean EMC of $10.9 \%(\mathrm{NCh} 176 / 1)$ and a mean density of $470 \mathrm{~kg} \cdot \mathrm{m}^{-3}$ (NCh176/2) according to Chilean standard, were machined using a single-spindle shaper (milling) machine with variable cutting speed and feed, with three hydro centered mounting cutter-heads of 6 knives HS6-5-2 (High Speed Steel type M2) with $26^{\circ}$ clearance angle and $15^{\circ}$ of rake angle each.

The machining takes into account a tool wear at a cutting distance of 0 to 10000 meters (linear cutting meters of material to be cut), with specific wear conditions, see Table 1.

Also in order to control and measure the tool wear, the cutting edge recession was measured with the help of a magnifying glass and software. Each 2000 meters of cutting distance, the machining conditions were adjusted, see Table 1, to assess the surface quality through the roughness and wettability surface properties. The mean peak-to-valley height $\left(R_{\mathrm{z}}\right)$ parameter, in accordance with ISO 4287 (1997) standard, was used to measure the roughness surface using a Mitutoyo SJ201 apparatus. On the other hand, wettability was measured by the principle of contact angle using a DSA25 Krüss device.

\section{RESULTS AND DISCUSSION 3. REZULTATI I RASPRAVA}

Table 2, below, shows the variation of average surface roughness in function of the cutting distance associated with the machining parameters. Independent of the

Table 1 Experimental conditions

Tablica 1. Uvjeti eksperimentalnih mjerenja

\begin{tabular}{|l|c|c|c|}
\hline \multicolumn{1}{|c|}{$\begin{array}{c}\text { Factors } \\
\text { Činitelji }\end{array}$} & $\begin{array}{c}\text { Wood } \\
\text { Drvo }\end{array}$ & $\begin{array}{c}\text { Tool Wear } \\
\text { Trošenje alata }\end{array}$ & $\begin{array}{c}\text { Surface quality measuring } \\
\text { Mjerenje kvalitete površine }\end{array}$ \\
\hline Density / gustoća & $470 \mathrm{~kg} \cdot \mathrm{m}^{-3}$ & & \\
\hline $\begin{array}{l}\text { Equilibrium Moisture content (EMC) } \\
\text { ravnotežni sadržaj vode (EMC) }\end{array}$ & $10.9 \%$ & & \\
\hline Tool diameter / promjer alata & & $192 \mathrm{~mm}$ & $15^{\circ}$ \\
\hline Rake angle / prsni kut & & $15^{\circ}$ & $22,30,38 \mathrm{~m} \cdot \mathrm{min}^{-1}$ \\
\hline Feed speed, $v_{\mathrm{f}}$ / posmična brzina, $v_{f}$ & & $26 \mathrm{~m} \cdot \mathrm{min}^{-1}$ & $44,50,56 \mathrm{~m} / \mathrm{s}$ \\
\hline Cutting speed, $v_{c} /$ brzina rezanja, $v_{c}$ & & $50 \mathrm{~m} / \mathrm{s}$ & each $2000 \mathrm{~meters}$ \\
\hline Cutting distance, L / duljina rezanja, $L$ & & 0 to $10000 \mathrm{~meters}$ & \\
\hline
\end{tabular}


Table 2 Variation of the average roughness $R_{\mathrm{z}}(\mu \mathrm{m})$ during Pinus radiata wood machining

Tablica 2. Varijacije srednje vrijednosti hrapavosti $R_{\mathrm{z}}(\mu \mathrm{m})$ tijekom obrade borovine

\begin{tabular}{|c|c|c|c|c|c|c|c|}
\hline \multirow{2}{*}{$\begin{array}{c}\text { Feed speed } v_{\mathrm{f}} \\
\text { Posmična brzina, } v_{\mathrm{f}} \\
\mathrm{m} \cdot \mathrm{min}^{-1}\end{array}$} & \multirow{2}{*}{$\begin{array}{c}\text { Cutting speed } v_{\mathrm{c}} \\
\text { Brzina rezanja, } v_{\mathrm{c}} \\
\mathrm{m} \cdot \mathrm{s}^{-1}\end{array}$} & \multicolumn{6}{|c|}{ Cutting distance, $\mathbf{m}$ / Duljina rezanja, $\mathrm{m}$} \\
\hline & & 0 & 2000 & 4000 & 6000 & 8000 & 10000 \\
\hline \multirow{3}{*}{22} & 44 & 21.0 & 20.3 & 26.5 & 27.8 & 27.3 & 25.2 \\
\hline & 50 & 21.9 & 20.5 & 25.5 & 27.0 & 25.9 & 24.3 \\
\hline & 56 & 19.9 & 19.3 & 23.8 & 23.9 & 25.5 & 23.9 \\
\hline \multirow{3}{*}{30} & 44 & 22.4 & 20.7 & 26.8 & 29.5 & 32.2 & 26.9 \\
\hline & 50 & 20.5 & 21.2 & 25.6 & 26.7 & 28.4 & 24.7 \\
\hline & 56 & 18.6 & 18.6 & 24.0 & 25.6 & 26.5 & 24.2 \\
\hline \multirow{3}{*}{38} & 44 & 20.7 & 19.8 & 26.9 & 25.7 & 25.1 & 26.2 \\
\hline & 50 & 20.5 & 19.6 & 26.3 & 27.4 & 28.6 & 28.4 \\
\hline & 56 & 20.7 & 19.4 & 27.3 & 28.7 & 25.5 & 25.4 \\
\hline
\end{tabular}

machining conditions, the average roughness decreases from its initial level at 0 meters until 2000 meters and then increases again until the cutting distance of 8000 meters; then it shows a gentle tendency to diminish.

When the roughness is compared in function of the cutting speed, roughness tends to diminish as the cutting speed $v_{\mathrm{c}}$ increases. On the other hand, when the comparison is related to feed speed, there is a slight increase of the roughness as feed speed $v_{\mathrm{f}}$ increases. These trends become more consistent when the comparison is made among conditions of $v_{\mathrm{f}}$ (22 to 38 $\mathrm{m} \cdot \mathrm{min}^{-1}$ ) and as the cutting distance increases. Table 3 shows the average contact angle in function of the cutting distance and machining conditions. In general, it does not show a clear trend through the cutting dis- tance, or with the cutting speed. However, when comparison is made based on the cutting distance of 0 meter and 10000 meter, the contact angle changes depending on the feed speed. In case of feed speed of 22 and $38 \mathrm{~m} \cdot \mathrm{min}^{-1}$, the surface wetting tends to decrease with the cutting distance, i.e. higher contact angle at 10000 meters than 0 meters.

The statistical analysis, ANOVA, see Table 4, shows that the cutting distance $(L)$ is the most significant factor for roughness $\left(R_{\mathrm{z}}\right)$. It is followed in importance by the cutting speed $\left(v_{c}\right)$, and only then by the feed speed $\left(v_{\mathrm{f}}\right)$. In the case of wettability (contact angle), the most significant factor of variance is the feed speed $\left(v_{\mathrm{f}}\right)$ followed by the cutting distance $(L)$ and the cutting speed $\left(v_{\mathrm{c}}\right)$ as the least important.

Table 3 Variation of average contact angle $\theta\left(^{\circ}\right)$ during Pinus radiata wood machining

Tablica 3. Varijacije srednjega kontaktnog kuta kvašenja površine $\theta\left(^{\circ}\right)$ tijekom obrade borovine

\begin{tabular}{|c|c|c|c|c|c|c|c|}
\hline \multirow{2}{*}{$\begin{array}{c}\text { Feed speed } v_{\mathrm{f}} \\
\text { Posmična brzina, } v_{\mathrm{f}} \\
\mathrm{m} \cdot \mathrm{min}^{-1}\end{array}$} & \multirow{2}{*}{$\begin{array}{c}\text { Cutting speed } v_{\mathrm{c}} \\
\text { Brzina rezanja, } v_{\mathrm{c}} \\
\mathrm{m} \cdot \mathrm{s}^{-1}\end{array}$} & \multicolumn{6}{|c|}{ Cutting distance, $\mathbf{m}$ / Duljina rezanja, $\mathrm{m}$} \\
\hline & & 0 & 2000 & 4000 & 6000 & 8000 & 10000 \\
\hline \multirow{3}{*}{22} & 44 & 31.8 & 50.6 & 37.9 & 90.1 & 60.3 & 61.5 \\
\hline & 50 & 30.2 & 47.9 & 25.5 & 90.1 & 48.6 & 61.9 \\
\hline & 56 & 31.9 & 47.7 & 32.3 & 85.0 & 55.1 & 55.2 \\
\hline \multirow{3}{*}{30} & 44 & 28.6 & 21.2 & 19.8 & 46.7 & 22.4 & 20.6 \\
\hline & 50 & 29.2 & 21.3 & 25.5 & 23.2 & 28.3 & 15.7 \\
\hline & 56 & 35.1 & 25.1 & 24.9 & 26.7 & 24.8 & 18.5 \\
\hline \multirow{3}{*}{38} & 44 & 34.3 & 32.5 & 36.5 & 31.0 & 35.4 & 46.4 \\
\hline & 50 & 33.6 & 25.4 & 39.8 & 19.0 & 34.8 & 29.8 \\
\hline & 56 & 28.9 & 20.9 & 26.6 & 20.3 & 29.3 & 40.9 \\
\hline
\end{tabular}

Table 4 ANOVA of surface properties in function of cutting conditions and distance

Tablica 4. ANOVA analiza svojstava obrađene površine u ovisnosti o parametrima obrade i duljini rezanja

\begin{tabular}{|l|c|c|c|c|c|}
\hline $\begin{array}{l}\text { Roughness } \\
\text { Hrapavost }\end{array}$ & $\boldsymbol{D f}$ & Sum $\boldsymbol{S q}$ & Mean $\boldsymbol{S} \boldsymbol{c}$ & $\boldsymbol{F}$ value & $\operatorname{Pr}(>\boldsymbol{F})$ \\
\hline $\mathrm{L}$ & 5 & 8153.45 & 1630.69 & 110.22 & 0.0000 \\
\hline$v_{\mathrm{c}}$ & 2 & 503.30 & 251.65 & 17.01 & 0.0000 \\
\hline$v_{\mathrm{f}}$ & 2 & 126.28 & 63.14 & 4.27 & 0.0143 \\
\hline Residuals & 960 & 14203.16 & 14.79 & & \\
\hline $\begin{array}{l}\text { Contact angle } \\
\text { Kontaktni } \text { kut }\end{array}$ & 5 & 31494.08 & 6298.82 & 31.22 & 0.0000 \\
\hline $\mathrm{L}$ & 2 & 2467.21 & 1233.60 & 6.11 & 0.0023 \\
\hline$v_{\mathrm{c}}$ & 2 & 137211.76 & 68605.88 & 340.02 & 0.0000 \\
\hline$v_{\mathrm{f}}$ & 960 & 194103.55 & 201.77 & & \\
\hline Residuals & \multicolumn{5}{|l}{} \\
\hline
\end{tabular}


Table 5 Pearson correlation matrix between studied factors Tablica 5. Pearsonova korelacijska matrica između istraživanih utjecajnih činitelja

\begin{tabular}{|c|c|c|c|c|c|}
\hline & $L$ & $v_{\mathrm{c}}$ & $v_{\mathrm{f}}$ & $R_{\mathrm{z}}$ & $\theta$ \\
\hline$L$ & 1.00 & 0.00 & 0.00 & 0.46 & 0.17 \\
\hline$v_{\mathrm{c}}$ & & 1.00 & 0.00 & -0.14 & -0.07 \\
\hline$v_{\mathrm{f}}$ & & & 1.00 & 0.06 & -0.44 \\
\hline$R_{\mathrm{z}}$ & & & & 1.00 & 0.00 \\
\hline$\theta$ & & & & & 1.00 \\
\hline
\end{tabular}

Moreover, Pearson correlation shows similar tendencies. $R_{\mathrm{z}}$ behavior is most related to the effect of the cutting distances $(L)$ followed by the cutting velocity $\left(v_{\mathrm{c}}\right)$ and only then by the feed speed $\left(v_{\mathrm{f}}\right)$. In the case of contact angle $\theta$, the most related factor is the feed speed $\left(v_{\mathrm{f}}\right)$ followed by the cutting distance and only then by the cutting velocity, see Table 5 .

Based on the factor significance, the behavior of surface properties, roughness and wettability (contact angle), are presented below in function of the cutting distance. The figures 1 to 4 represent the values as (+ main, - median, $T^{\perp} \min -\max$ and ${ }^{\circ}$ outliers).

Figure 1 shows the general behavior of surface roughness parameter $R$ in function of the cutting distance $(L)$. As can be seen, the $R_{\mathrm{z}}$ values decrease from 0 meter to 2000 meters, and then increase until 8000 meters, to decrease again when the cutting distance of 10000 meters has been completed. The above is consistent with a Duncan test that identifies three different groups of roughness through the cutting distance $(L), 0$ to 2000,4000 to 8000 , and 10000 meters, at a significance level of $0.05 \%$. Second in importance is the influence of the cutting speed $\left(v_{\mathrm{c}}\right)$, Figure 2 shows the well known effect of the cutting speed on roughness; it decreases as the cutting speed increases.

This effect on roughness appears consistent throughout the cutting distance. Nevertheless, the values of roughness for the same machining conditions change as the cutting distance accumulates. For example, up to the cutting speed of $44 \mathrm{~m} / \mathrm{s}$, at the cutting distance of 0 meter, the $R_{\mathrm{z}}$ is slightly greater than 25 $\mu \mathrm{m}$, but after the cutting distance of 8000 meters, the same machining conditions no longer generate the same level of roughness; it changes up to $25 \mu \mathrm{m}$.

The effect of cutting distance $(L)$ and feed speed $\left(v_{\mathrm{f}}\right)$ on surface wettability (contact angle) of Pinus radiate wood throughout the cutting distance are shown in Figure 3 and 4 . If the whole experiment design is considered, see Figure 3, it can be seen that the median and the average contact angle decrease until the minimum level when the cutting distance has reached 4000 meters, and then begin to rise steadily from 6000 meters on.

However, when the feed speed is plotted through the cutting distance, see Figure 4, its significance on wetting is evident.

Figure 4 shows how the contact angle evolves three different paths as the cutting distance increases. It could be said that the feed speed of $30 \mathrm{~m} \cdot \mathrm{min}^{-1}$ produced the most wettable surface, while the feed speed of $22 \mathrm{~m} \cdot \mathrm{min}^{-1}$ produced less wettable surface.

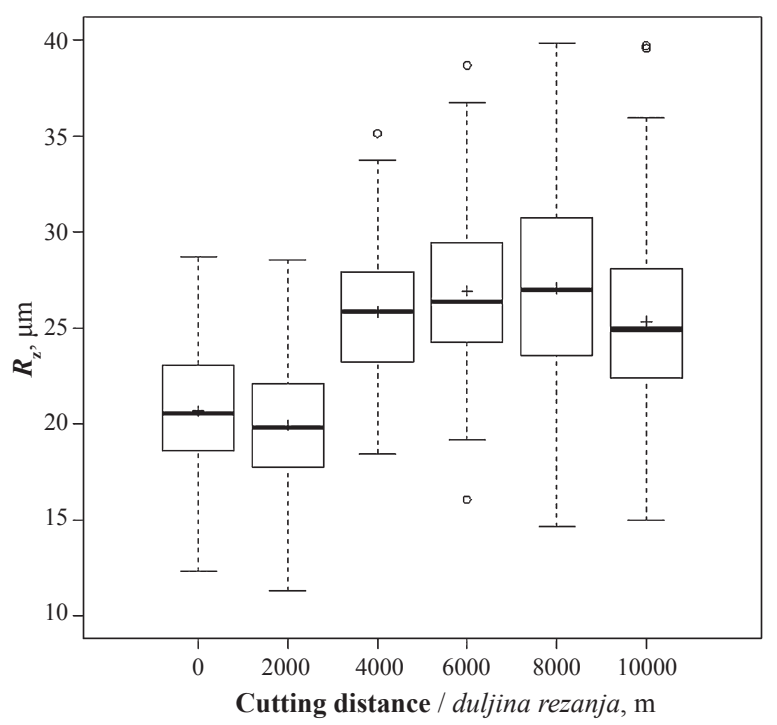

Figure 1 Surface roughness parameter $R_{\mathrm{z}}$ in function of cutting distance considering the whole experiment

Slika 1. Parametar hrapavosti površine $R_{\mathrm{z}}$ u ovisnosti o duljini rezanja tijekom cijelog eksperimenta

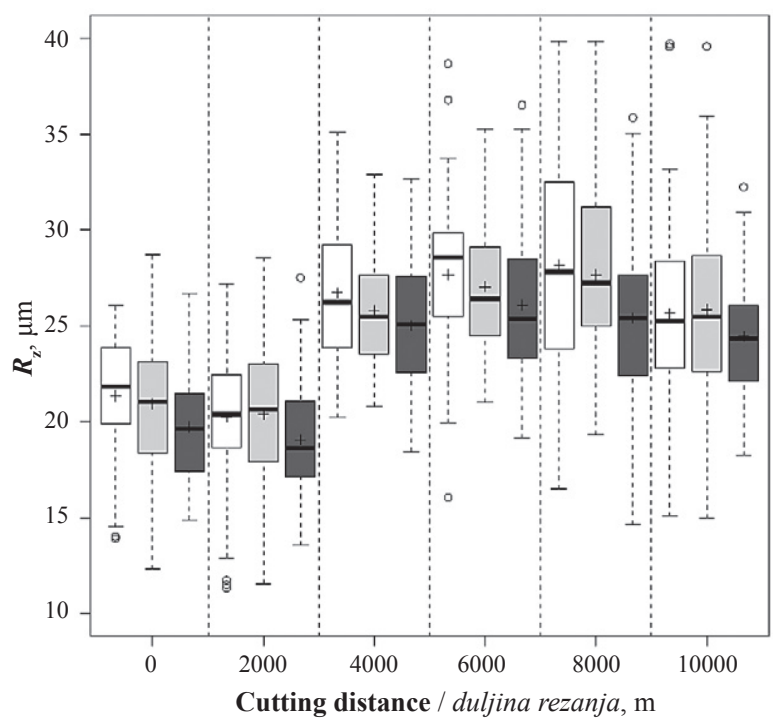

Figure 2 Surface roughness parameter $R_{\mathrm{z}}$ in function of cutting distance and cutting speed $v_{\mathrm{c}}$ (white $44 \mathrm{~m} / \mathrm{s}$, grey 50 $\mathrm{m} / \mathrm{s}$ and black $56 \mathrm{~m} / \mathrm{s}$ ) considering the whole experiment Slika 2. Parametar hrapavosti površine $R_{\mathrm{z}}$ u ovisnosti o duljini i brzini rezanja $v_{\mathrm{c}}$ (bijela $44 \mathrm{~m} / \mathrm{s}$, siva $50 \mathrm{~m} / \mathrm{s}$, crna 56 $\mathrm{m} / \mathrm{s}$ ) tijekom cijelog eksperimenta

Regarding the wear of the cutting tool, Figure 5 shows a comparison of cutting edges at the cutting distance of 0 meters and a dull condition of the knives after 10000 meters. The total average accumulated wear was of $3.5 \mu \mathrm{m}$. Both the Rake Face and the Clearance Face showed modifications to its original geometry. As shown in Figure 5, the most variable region is the so called land wear located on the Clearance Face. Future studies should focus on measuring this region through the cutting distance.

In this study, the behavior of roughness and wetting is described through the cutting distance. As it is well known, wettability is a thermodynamic response 


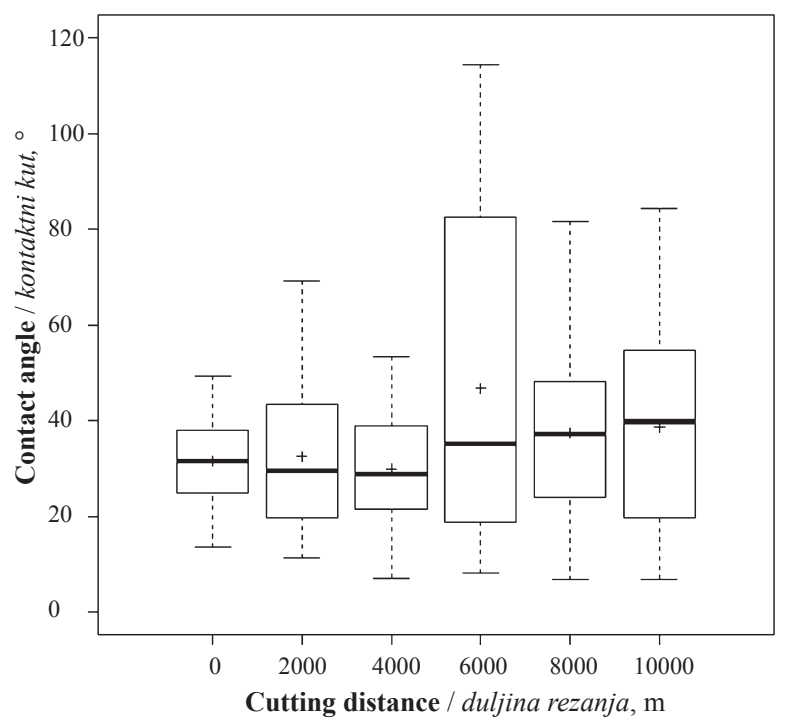

Figure 3 Contact angle $\theta$ in function of cutting distance considering the whole experiment

Slika 3. Kontaktni kut kvašenja površine $\theta$ u ovisnosti o duljini rezanja tijekom cijelog eksperimenta

to physical and chemical properties of wood surfaces (Tshabalala, 2005). Apparently, chemical properties would be playing a more important role than physical properties, and their influence on wettability of a wood surface would be related in part to the wear of the cutting tool as a result of the cutting distance. This assumption is based on the null correlation found among roughness and wettability in this study. Hansson et al. (2011) indicate that surface roughness failed to correctly predict the contact angle on a heterogeneous surface with chemical or topological heterogeneities covered by the droplet. Frybort et al. (2014) explain that variability in wettability of a surface is largely determined by surface chemistry, besides other factors such

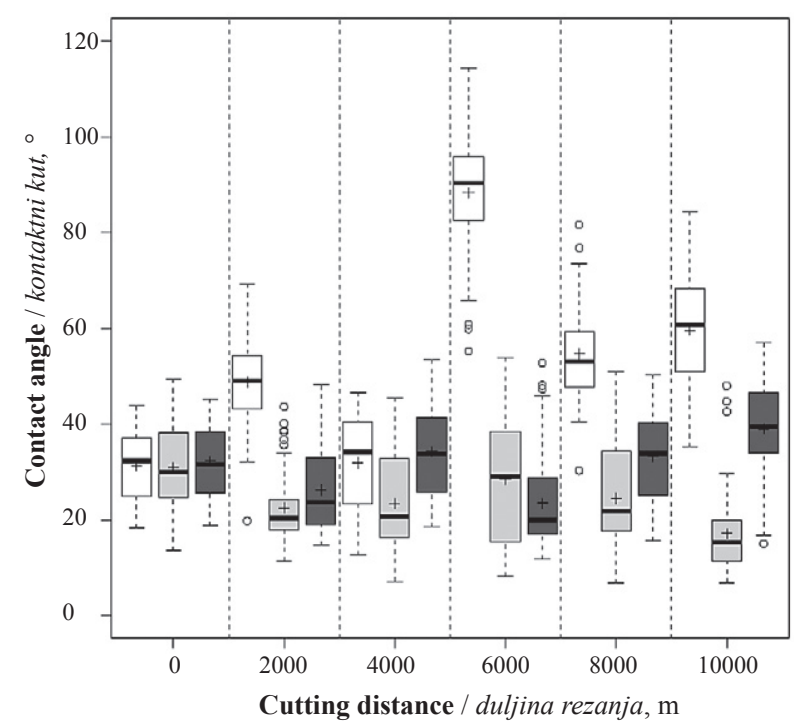

Figure 4 Contact angle $\theta$ in function of cutting distance and feed speed (white $22 \mathrm{~m} / \mathrm{min}$, grey $30 \mathrm{~m} / \mathrm{min}$ and black $36 \mathrm{~m} /$ min) considering the whole experiment

Slika 4. Kontaktni kut kvašenja površine $\theta$ u ovisnosti o duljini rezanja i posmičnoj brzini $v_{\mathrm{f}}$ (bijela $22 \mathrm{~m} / \mathrm{min}$, siva $30 \mathrm{~m} / \mathrm{min}$, crna $36 \mathrm{~m} / \mathrm{min}$ ) tijekom cijelog eksperimenta

as e.g. surface roughness, and conclude that differences in polarity between freshly cut cell walls and native inner lumen surfaces correlate with chemical heterogeneity. Apparently, the wear of the cutting tool, related to the cutting distance, produced a variation in the exposure of the chemical components of the wood ultrastructure and determined the thermodynamic behavior of the machined surface.

\section{CONCLUSION \\ 4. ZAKLJUČAK}

The monitoring of the surface properties through the cutting distance has allowed a correlation to be
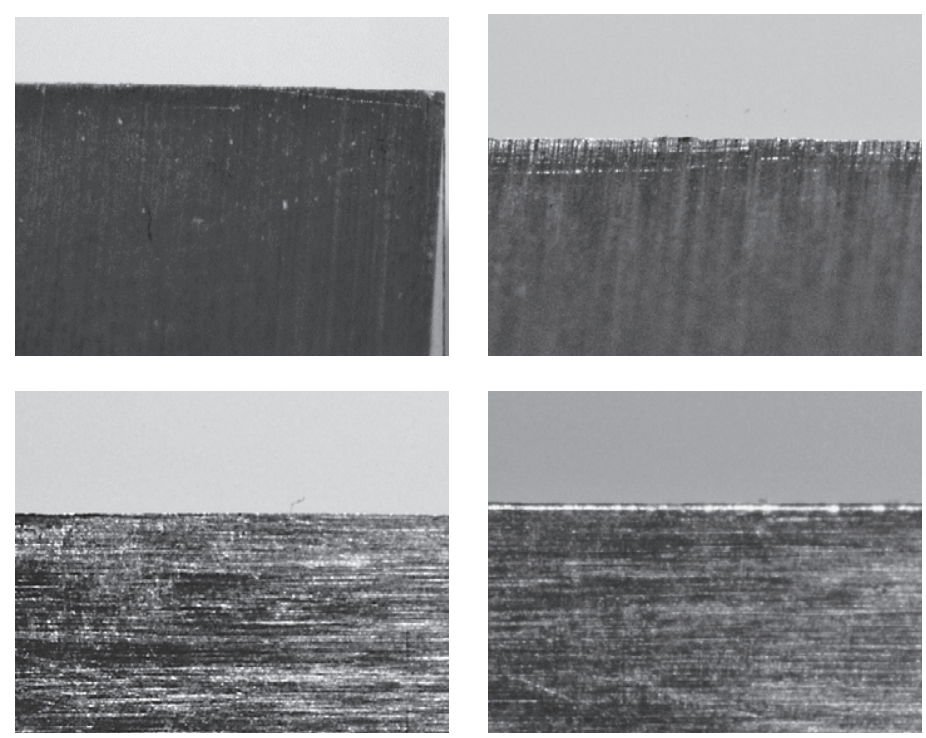

Figure 5 Cutting edge wear samples: cutting distance of 0 (left) to 10000 meters (right) Clearance Face (above) and Rake Face (below)

Slika 5. Primjeri trošenja oštrice alata: duljina rezanja $0 \mathrm{~m}$ (lijevo) i duljina rezanja $10000 \mathrm{~m}$ (desno), leđna strana oštrice (gore) i prednja strana oštrice (dolje) 
made between the wear of a cutting tool and the wettability of a machined surface. It is not reliable to explain the wettability of machined surfaces considering only the surface roughness on a heterogeneous surface such as wood. It is necessary to continue this study of the effect of the cutting distance with assessing changes in the surface chemistry and its relation with the thermodynamics of machined wood surfaces.

\section{Acknowledgments - Zahvala}

The authors would like to thank the Research and Development (DID) and the Faculty of Forest Science and Natural Resources Austral University of Chile, as well as, to the National Commission for Scientific and Technological Research CONICYT particularly the FONDECYT program which financed the development of this research through the project FONDECYT No. 1120347

\section{REFERENCES}

5. LITERATURA

1. Aknouche, H.; Outahyon, A.; Nouveau, C.; Marchal, R.; Zerizer, A.; Butaud, J., 2009: Tool wear effect on cutting forces: In routing process of Aleppo pine wood. Journal of Materials Processing Technology, 209: 2918-2922. http://dx.doi.org/10.1016/j.jmatprotec.2008.06.062.

2. Cool, J.; Hernández, R., 2011: Improving the sanding process of black spruce wood for surface quality and water-based coating adhesion. Forest Products Journal, 61 (5): 372-380. http://dx.doi.org/10.13073/0015-7473-61.5.372.

3. Dundar, T.; Akbulut, T.; Korkut, S., 2008: The effects of some manufacturing factors on surface roughness of sliced Makore (Tieghemella hechelii Pierre Ex A. Chev.) and rotary-cut beech (Fagus orientalis L.) veneers. Building and Environment, 43: 469-474. http://dx.doi.org/10.1016/j.buildenv.2007.01.002.

4. Frybort, S.; Obersriebnig, M.; Müller, U., Gindl-Altmutter, W.; Konnerth, J., 2014: Variability in surface polarity of wood by means of AFM adhesion force mapping. Physicochem. Eng. Aspects, 457: 82-87. http://dx.doi.org/10.1016/j.colsurfa.2014.05.055.

5. Gilewicz, A.; Warcholinski, B.; Myslinski, P.; Szymanski, W., 2010: Anti-wear multilayer coatings based on chromium nitride for wood machining tools. Wear, 270: 32-38. http://dx.doi.org/10.1016/j.wear.2010.09.002.

6. Hansson, P.; Skedung, L.; Claesson, P.; Swerin, A.; Schoelkopf, J.; Gane, P.; Rutland, M.; Thormann, E., 2011: Robust hydrophobic surfaces displaying different surface roughness scales while maintaining the same wettability. Langmuir, 27: 8153-8159. http://dx.doi.org/10.1021/la201121p.
7. Hernández, R.; Cool, J., 2008: Effects of cutting parameters on surface quality of paper birchwood machined across the grain with two planing techniques. Holz Roh Werkst, 66: 147-154.

http://dx.doi.org/10.1007/s00107-007-0222-4.

8. Itaya, S., Tsuchiya, A., 2003: Development of CrN coated tool to create smooth surface of solid wood aiming to mit sanding process in furniture production. Proceeding of the $16^{\text {th }}$ International Wood Machining Seminar, Matsue, Japan, pp. 74-81.

9. Keturakis, G.; Juodeikienè, I., 2007: Investigation of milled wood surface roughness Materials science (Medžiagotyra), 13 (1).

10. Keturakis, G.; Lisauskas, V., 2010: Influence of the sharpness angle on the initial wear of the wood milling knives. Materials science (Medžiagotyra), 16 (3).

11. Magoss, E., 2008: General regularities of wood surface roughness. Acta Silv. Lign. Hung., 4: 81-93.

12. NCh 176/1: Wood Part 1: Determination of moisture content for physical and mechanical tests. Instituto Nacional de Normalización INN. Eq: ISO 3130:1975.

13. NCh 176/2: Wood Part 2: Determination of density for physical and mechanical tests. Instituto Nacional de Normalización INN. Eq: ISO 3131:1975.

14. Santoni, I.; Pizzo, B., 2011: Effect of surface conditions related to machining and air exposure on wettability of different Mediterranean wood species. International Journal of Adhesion \& Adhesives, 31: 743-753. http://dx.doi.org/10.1016/j.ijadhadh.2011.07.002.

15. Sheikh, J.; McKenzie, W., 1997: Measurement of tool wear and dulling in the machining of particleboard. Proceedings of the 13th International wood machining seminar, June 17-20, Vancouver, Canada.

16. Tshabalala, M., 2005: Surface Characterization. Handbook of Wood Chemistry and Wood Composites. Chapter 8: 187-209.

17. Walinder, M., 2000: Wetting phenomena on wood. Factors influencing measurements of wood wettability. Doctoral Thesis KTH-Royal Institute of Technology, Wood Technology and Processing, 62 pp.

\section{Corresponding address:}

Assist. Prof. ALDO ROLLERI S., Ph.D.

Forest Products Laboratory

Institute of Forest and Society

Faculty of Forest Science and Natural Resources

University Austral of Chile

Campus Isla Teja, Casilla 567, Valdivia

CHILE

e-mail: arolleri@uach.cl 